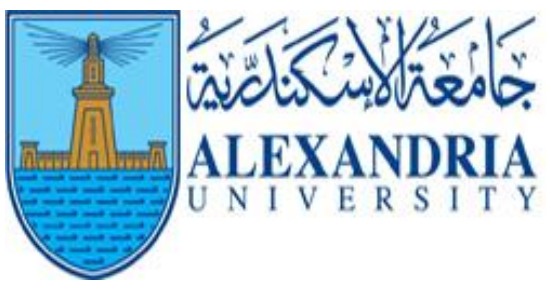

Faculty of Arts

Greek and Roman Archaeology and studies Department.

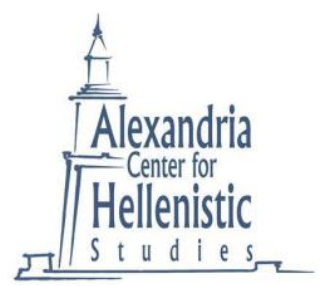

Alexandria Center for Hellenistic Studies (ACHS)

\title{
Evidences of the Artistic Assimilation through studying the Ptolemaic Incense Burners
}

Maha Mohamed Hassan.

(2018) 



\section{Abstract}

Generally, ancestors have used incense in their temples as offerings ${ }^{1}$ in the religious rituals and purification. Moreover, it used at houses for the domestic cult practices as in our lifestyle nowadays. There were many kinds of incense in ancient Egypt such as Myrrh from the old kingdom and also frankincense that found in the tomb of the king Tutankhamen. ${ }^{2}$ It's necessary to mention that the incense burners were known in the ancient civilizations and cultures such as Egypt, Asia, Greece and Etruria. Incense burners were characterized by the local features that have been changed and modified according to the variety of places and sequential years.

In the consideration, the Hellenistic period was reflecting a great phenomenon of the Artistic Assimilation that happened. Egypt was one of the famous kingdoms that appeared after the death of Alexander the great. Thus, Egypt under the control of the Ptolemies comprehended the Greek culture and maintained the local Egyptian one. Obviously, Egyptians and Greeks accepted the socio-culture coexistence before the Hellenistic period according to the Greek settlements that found in Egypt. ${ }^{3}$

Indeed the Ptolemaic kings tended to rapprochement the Egyptians thought and aimed to make themselves close to them. They were imitating the Egyptian's lifestyle traditions specially the clothes and crowns. Ptolemies also were represented while practicing the ritual of burning incense to the Egyptian deities on the temple's relief.

\footnotetext{
${ }^{1}$ Alan B. Lioyd, A companion to Ancient Egypt, Wiley-Blackwell publishing Ltd. UK, 2010, Vol. I, 262.

${ }^{2}$ Aitken, J. and others, On Stone and Scroll: Essays in Honour of Graham Ivor Davies, Walter de Gruyter, 2011, 112.

${ }^{3}$ Matthews R., Roemer C. Ancient Perspectives on Egypt, CRC, 2003, 11.
} 
Thus, this paper intends to show the variety of incense burner's types. For recognizing the local type of Egyptian incense burner before the Ptolemaic period and how it continued through it. In addition, it is going to shed light on other styles that appeared also in the Ptolemaic Egypt.

\section{Incense burner before the Ptolemaic period}

As a matter of fact, the Egyptian style of incense burner was appeared in the form of outstretching arm (Cat.1) $)^{4}$. The outstretching arm means the verb "giving" in Hieroglyphic writing. The falcon's head in the end of the arm and incense bowl on the center are representing the Eye of Horus for his healing or protection powers. The falcon's head itself considered as a symbol of the god Horus. ${ }^{5}$

Some archaeological finds in Heracleion are intensifying the commercial interaction between Egypt and other places before the Hellenistic period. For sure, the artistic interactions were occurred as a normal result of the cultural friction. Sphinx incense burner (Cat.2) ${ }^{6}$ is Cypriot type that representing in the form of female sphinx statue and made of limestone. Its body is sculpting well with missing legs, and wearing a collar on the neck. It is rising up wings in the shape of two rows of long feathers. Prominent features are reflecting large lower lip, broken nose, wide eyes, uncovered ears, long hair in beads shape. The deep incense's bowl is based on the wings and the head's crown that appeared in four bands of square beads and Zigzag band above it. Egypt was known the male sphinx as a symbol of the Egyptian king's power. Moreover, the Greeks and Cypriots

\footnotetext{
${ }^{4}$ https://www.brooklynmuseum.org/opencollection/objects/3810 21-7-2017

${ }_{5}^{5}$ Murphy, T. Cracking the Symbol Code - The Heretical Message within Church and Renaissance Art, Duncan Baird, 2011, 21.

${ }^{6}$ http://britishmuseum.tumblr.com/post/148341930687/cypriot-female-sphinx $16-10-2017$
} 
imitated that creature but in female form with a new function as a guardian of the underworld's border. ${ }^{7}$

\section{Incense burner through Ptolemaic period}

The Greek settlements that found in Egypt were emphasizing the social and political interactions. Naucratis ${ }^{8}$ was one of them that revealed another incense burner style (Cat.3) ${ }^{9}$. The body is appearing as cylindrical stem that and decorating with Uraeus turning around in coil shape and raising up its head. The main decorative element is Uraeus with symbolic meaning of royalty and kingship's power at Egypt. ${ }^{10}$ Also, there are four simple bands around the top of the body and abacus to hold the incense bowl. On the top, the bowl is representing as open rosettes form and flat part on the central surface with damaged parts under it (Parts of the bowl and base are now missing).

Moreover, another style of horned incense burner from Tell Atrib (Cat.4) has burning traces with domestic cult function. It is standing on four rectangular hooves as base, cylindrical stem dividing into three parts: two are plain and the middle decorating with trunk, vine scrolls, myrtle and grapes. Incense bowl is representing in horned form on the corners and small triangles between them and decorating with Anthemion (Lotus palmettes). This type is found also in tombs as in Mustapha Pasha necropolis and Taposiris Magna with funeral function ${ }^{11}$. Naos incense

\footnotetext{
${ }^{7}$ Hotema, H. The Mysterious Sphinx, Health Research Books, 1996, 7.

${ }^{8}$ https://www.britannica.com/place/Naukratis 9-10-2017

${ }^{9}$ http://www.britishmuseum.org/research/collection_online/collection_object details.aspx?o bjectId=407721\&partId=1\&searchText=ptolemaic \&view=list\&sortBy=imageName\&page $=$ 19 10-10-2017

${ }^{10}$ Stanwick, P. Portraits of the Ptolemies: Greek Kings as Egyptian Pharaohs, University of Texas, 2010, 34.

${ }^{11}$ Tybulewicz, R. Two Terracotta Incense Burners with 'Horns' and Vine Scroll Decoration from Tell Atrib (Egypt), Études et Travaux XXVIII, 2015, 191-200.
} 
burner as architectural building (Cat.5) ${ }^{12}$ with burning traces on the bowl surface. It is representing in square form with four columns in the corners that ending with bases (some missing). Next level is forming frontal façade with central square hole that has a symbolic item inside as referring to the god's statue. ${ }^{13}$

Touch el-Karamus from Alexandria is column incense burner $\left(\right.$ Cat.6) ${ }^{14}$ formed in Architectural element with curved arises flutes ${ }^{15}$. It is forming as four legs of standing Sirens ${ }^{16}$ on bases and round plinth decorating with corymb as base of incense burner. The stem is appearing in curved flutes, chevron and circular band. The incense bowl is decorating with semicircular rim. The lid is dividing into three bands: two of them decorating with loti forms and the third with palmate. On the top, there is vertical handle; the reconstruction is referring to it as a base for standing rooster ${ }^{17}$. The incense burner with lid manufactured in Egypt as $\left(\right.$ Cat.7) ${ }^{18}$ that covered with tiered lid. It is depicting simple slim body standing on tripod. This incense burner is representing between two priests who holding a sacred bull "could be Apes Bull" on their shoulders during a ritual event or festival.

\footnotetext{
${ }^{12}$ http://www.britishmuseum.org/research/collection_online/collection_object_details.aspx? objectId=407654\&partId=1\&searchText=ptolemaic\%20altar\&matcult=15634\&page $=128$ $11-2017$

${ }^{13}$ Thomas, R. Masson, A. "Altars, sundials, minor architectural objects and models", Naucratis: Greeks in Egypt, The British Museum, 7.

${ }^{14}$ Pfrommer, M. "II Thymiaterion", Studien Zu Alexandrinischer Und Grossgriechischer Toreeutik Frühhellenistischer Zeit, Archäologische Forschungen Band 16, pp. 25-41, Deutsche Archäologisches Institut, Berlin. 1987, 25-41.

${ }^{15}$ Cunningham and others, Culture and Values: A Survey of the Humanities, Vol. 1, Cengage, 2009, 44.

${ }^{16}$ Siren: Mythological creature of half bird and half woman. https://www.britannica.com/topic/Siren-Greek-mythology 11-5-2018.

${ }^{17}$ Stone, E. A Buddhist Incense Burner from Gandhara, Metropolitan Museum Journal, Vol. 39, pp. 69-99, The University of Chicago Press on behalf of The Metropolitan Museum of Art, 2004, 84.

${ }^{18} \mathrm{http}: / /$ www.britishmuseum.org/research/collection_online/collection_object_details.aspx? objectId=420456\&partId=1\&matcult=15634\&page=35 12-10-2017
} 
Indeed Egypt wasn't only accepted and observed the Greek culture but also kept its own features and traditions. Specially, the local Egyptian style of incense burners continued through the Ptolemaic and Roman periods. An example of Egyptian incense burner style (Cat.8) ${ }^{19}$ is depicting in outstretched arm shape that holding a figure setting on the central forearm. There is a box or table (could be used for keeping the unused incense before burn) in front of the figure. This figure is holding cartouche on his hips so, could be representing a king or priest who offering incense for Egyptian gods. Usually, the hand is holding a bowl for burning incense (now missing) and the Falcon's head is appearing at the end of the arm. More example of bronze incense burner in Egyptian style (Cat.9) ${ }^{20}$ is depicting outstretching arm with two different forms and sizes of incense bowls. One oblique long bowl is appearing on the hand and another short one on the forearm. At the end of the arm, there is a falcon's head holding the sun disk with Uraeus on his head. Uraeus is a symbol of various things as the sun, Lower Egypt, the king, rearing up and protection. ${ }^{21}$ These examples are revealing the continuity of the Egyptian style of incense burners under the Ptolemaic control.

\section{The Ptolemaic kings and Egyptian traditions coexistence:}

The Ptolemaic kings were tended to make themselves close to the Egyptians by practicing same rituals to their deities. In hence, there are many temples reliefs that depicted the

\footnotetext{
${ }^{19} \mathrm{http}: / /$ www.britishmuseum.org/research/collection_online/collection_object_details.aspx? objectId $=140809 \&$ partId $=1 \&$ page $=64 \&$ searchText $=$ \&images $=$ true $\&$ people $=\&$ place $=\&$ fro $\underline{\mathrm{m}}=\mathrm{bc} \&$ fromDate $=5000 \& \mathrm{to}=\mathrm{ad} \&$ toDate $=600 \&$ object $=\&$ subject $=\&$ matcult $=\&$ technique $=\& \mathrm{~s}$ $\underline{\text { chool }=\& \text { material }=\& \text { ethname }=\& \text { ware }=\& \text { escape }=\& \text { museumno }=\& \text { bibliography }=\& \text { citation }=\&}$ peo $\mathrm{A}=\&$ plaA$=\&$ term $A=\&$ sortBy $=\&$ view $17-10-2017$

${ }^{20}$ http://collections.rom.on.ca/objects/189013/incense-censer?ctx=855ab6c9-96af-4a8f-

9a7d-c7ff08e11b71\&idx=8 14-10-2017

${ }^{21}$ http://collections.rom.on.ca/objects/189013/incense-censer?ctx=855ab6c9-96af-4a8f9a7d-c7ff08e11b71\&idx=8 14-10-2017
} 
Ptolemaic kings offering Egyptian incense burner. According to Fraser, the Ptolemaies followed the Egyptians tradition in worshiping the rulers "Dynastic cult" and assumed new titles for them. ${ }^{22}$

The altar's Hall at Edfu temple (Cat.10), is depicted the king Ptolemy IV (Philometor) offering incense burner decorating with falcon's head and sun disk to Euergetes I and Berenice II. On the East staircase in same temple (Cat.11) is representing Cleopatra and Ptolemy VIII (Euergetes II) giving offerings as incense burner. ${ }^{23}$

On the south wall in Dendera temple (Cat.12) ${ }^{24}$, Cleopatra VII and Ptolemy XV (Caesarion) are representing on the right and left of the relief in front of them Egyptian gods ${ }^{25}$. He is wearing the ram's horns under the double crown and holding the Egyptian incense burner.

At Kom Ombo (Cat.13) ${ }^{26}$ there is a relief in Sobek and Haroeris ${ }^{27}$ temple that depicting Ptolemy VI (Philometor) standing in front of the Egyptian gods who sitting on thrones. He is wearing Egyptian crowns ${ }^{28}$ and offering incense burner that decorated with crouching sphinx motif. In essence, these various evidences are pointing to one of the Ptolemaic aims that they have been rapprochement the Egyptians thought and tried to imitate their life style traditions.

\footnotetext{
${ }^{22}$ Fraser, P. Ptolemaic Alexandria: Text, Oxford University, 1972, Vol. 1, 213.

${ }^{23}$ Markaz Tasjil al Athar al Misriyah, Maabad Edfu: Le temple d'Edfou, Vol.1, al Kutayyibat al thaqafiyah, Cairo, 2008, 8.

${ }^{24}$ Prudence J. Jones, Cleopatra: A Sourcebook, Volume 31, University of Oklahoma, 2006, 21.

${ }^{25}$ Ann Ashton, S. Cleopatra and Egypt, John Wiley \& Sons, 2009, 92-94.

${ }^{26} \mathrm{http}$ ///www.gettyimages.com/detail/photo/offering-scene-relief-temple-of-sobek-andhigh-res-stock-photography/639560649 2-11-2017

${ }^{27}$ Haroeris: The elder Horus and in that temple he is the son of the sun god Lurker, 1984, 74.

${ }^{28}$ Yoyotte, J. Vernus, P. The Book of the Pharaohs, Cornell University, 2003, 55.
} 


\section{Conclusion}

Incense burner as a value object was known in the Egyptian civilization with own characteristic style. The archaeological finds were intensifying the ancient commercial communications. Thus, the artistic interactions occurred as a normal result of the cultural friction even before the Hellenistic era.

Egypt wasn't only kept its features and traditions but also accepted and observed the Greek culture. The Ptolemaic incense burners manufactured in various types and modified with other artistic elements. It could be form in cylindrical stem with round or horned incense bowl also appeared in architectural shape as Naos and Column. Sometimes, the incense bowl covered with lid that has hollows to let the burning fumigation out.

The Ptolemaic kings were rapprochement the Egyptian thought and lifestyle's traditions. They tended to be close by imitating the Egyptian ritual practices as burning incense to their deities. That is the reason of Egyptian style continuity through the Ptolemaic era and even Roman period.

The context of the archaeological sites helps in recognizing the incense burner's functions that extracting from excavations. Tombs are referring to the funeral function; temples relating to the religious rituals and homes for domestic cult and daily usages.

\begin{tabular}{|c|l|l|l|}
\hline \multicolumn{1}{|c|}{ Sites } & \multicolumn{1}{c|}{ Temples } & \multicolumn{1}{c|}{ Tombs } & Homes \\
\hline Functions & $\bullet \begin{array}{l}\text { Religious } \\
\text { rituals } \\
\bullet\end{array}$ & Funeral usage & $\begin{array}{l}\text { Domestic } \\
\text { cult } \\
\end{array}$ \\
& $\begin{array}{l}\text { Offerings } \\
\text { Daily use. }\end{array}$ \\
\hline
\end{tabular}




\section{$\underline{\text { Catalogue }}$}

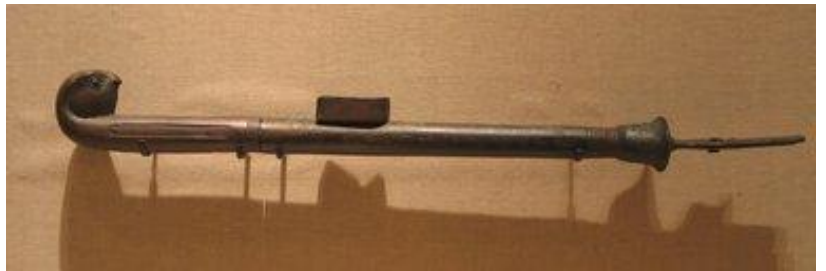

(Cat.1) Egyptian incense burner

Date: Old Kingdom to $18^{\text {th }}$ Dynasty.

Dimensions: 5.7 x $54.5 \mathrm{~cm}$.

Material: Bronze.

Provenance: Egypt.

Inventory: 72.8. Brooklyn Museum, Gift of Michael Debry.

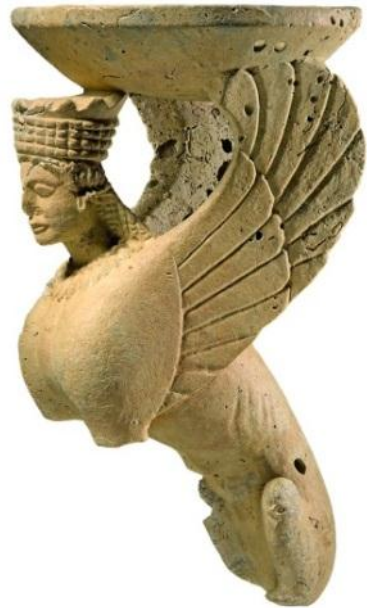

(Cat.2) Cypriot incense burner

Date: Classical period.

Dimensions: 22.9 x 11.1 x $17.5 \mathrm{~cm}$.

Material: Limestone.

Provenance: Egyptian city of Thonis- Heracleion.

Inventory: 74.51.2814, National Museum of Alexandria. 


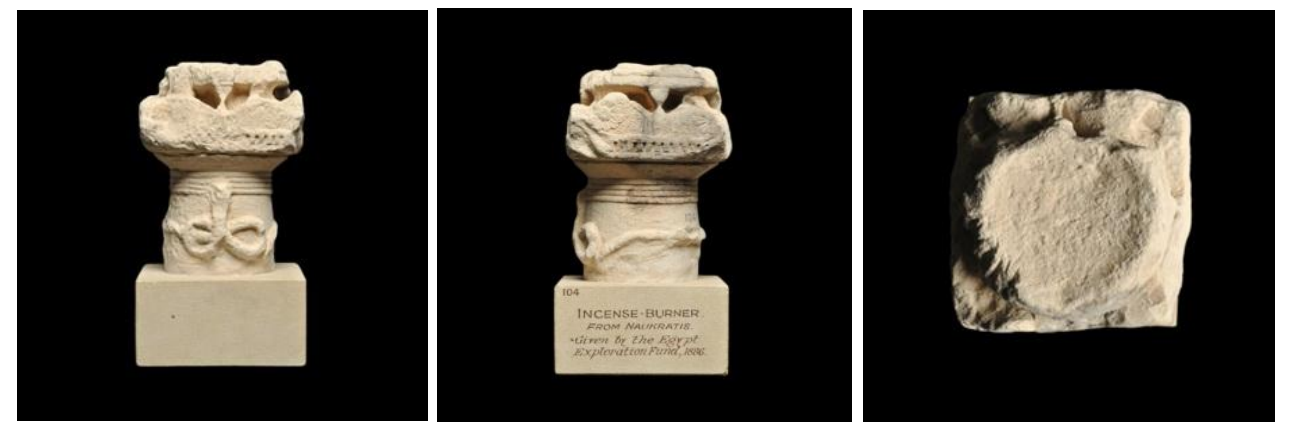

(Cat.3) Incense burner decorated with Uraeus

Date: $400-200$ BC.

Dimensions: H. $11.5 \mathrm{~cm}$.

Material: Limestone.

Provenance: Naucratis, Lower Egypt.

Inventory: 1886, 0401.1567, The British Museum.

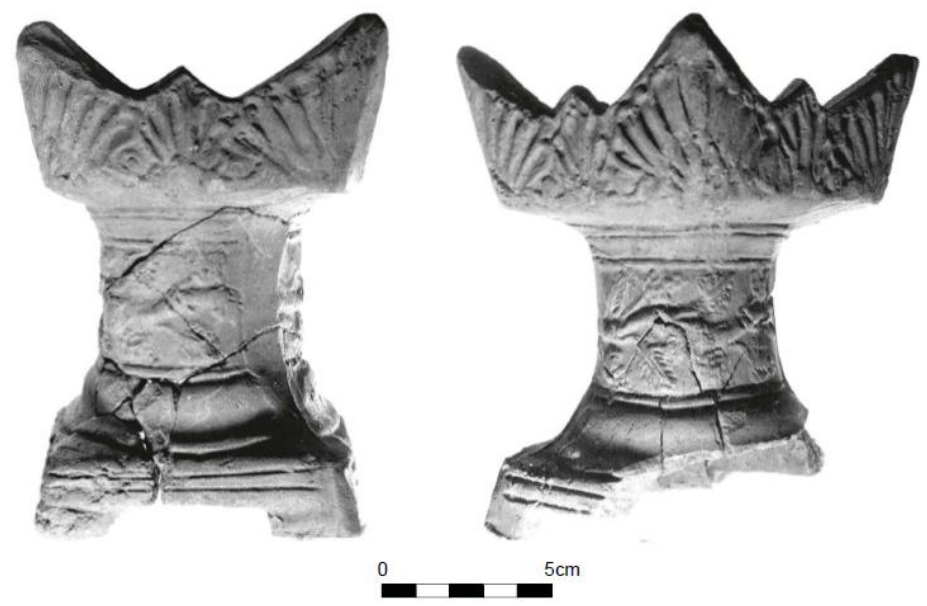

(Cat.4) Incense burner decorated with vine scroll.

Date: Ptolemaic period.

Dimntions: H. 13.2, W. $9.9 \mathrm{~cm}$.

Material: Terracotta.

Provenance: Southern wall of room no. 171, Tell Atrib. Inventory: TA 89/166, excavation of Tell Atrib, Egypt. 

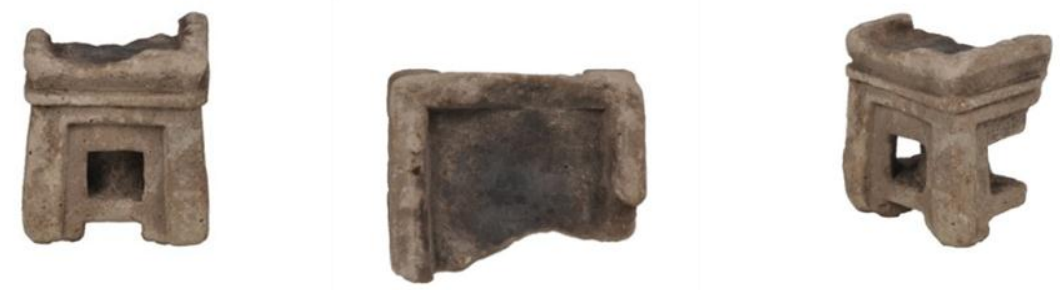

(Cat.5) Naos Incense burner

Date: 300 BC.

Dimensions: H. $9.1 \mathrm{~cm}$.

Material: limestone.

Provenance: Naukratis, Lower Egypt.

Preserved: 1909,1201.4, The British Museum.
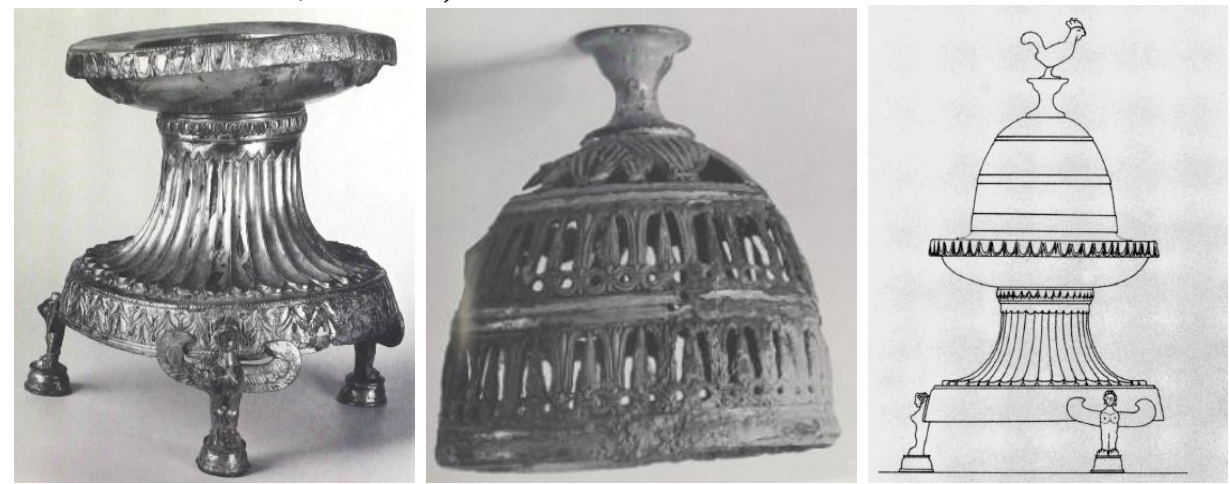

(Cat.6) Touch el-Karamus incense burner decorated with flutes Date: $4^{\text {th }}$ B.C.

Material: Silver.

Provenance: Karamus, Alexandria.

Inventory: JE 38089, JE 38090, Egyptian Museum. 


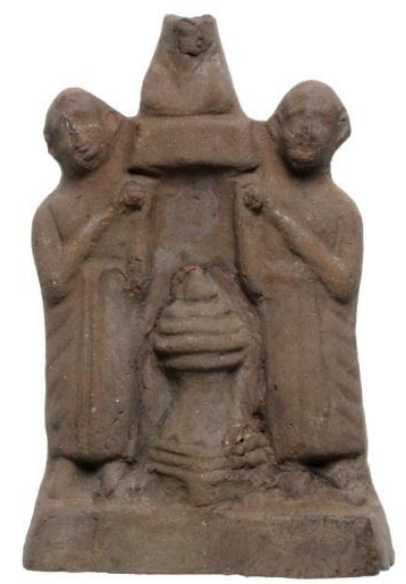

(Cat.7) relief of two priests and incense burner Date: $2^{\text {nd }}-1^{\text {st }}$ Century B.C.

Dimensions: H. $15 \mathrm{~cm}$.

Material: Terracotta.

Provenance: Egypt.

Inventory: 1921, 1220.119, The British Museum.

Date: $4^{\text {th }}-2^{\text {nd }}$ Century B.C.

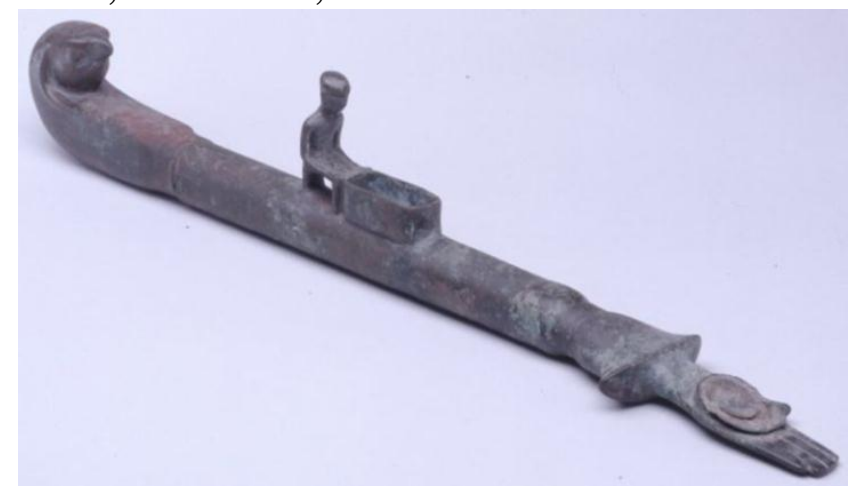

(Cat.8) Egyptian incense burner

Dimensions: L. 50.4, H. 9.15, W. $3.79 \mathrm{~cm}$.

Material: Bronze.

Provenance: Saqqara, Egypt.

Inventory: EA67189, the British Museum. 


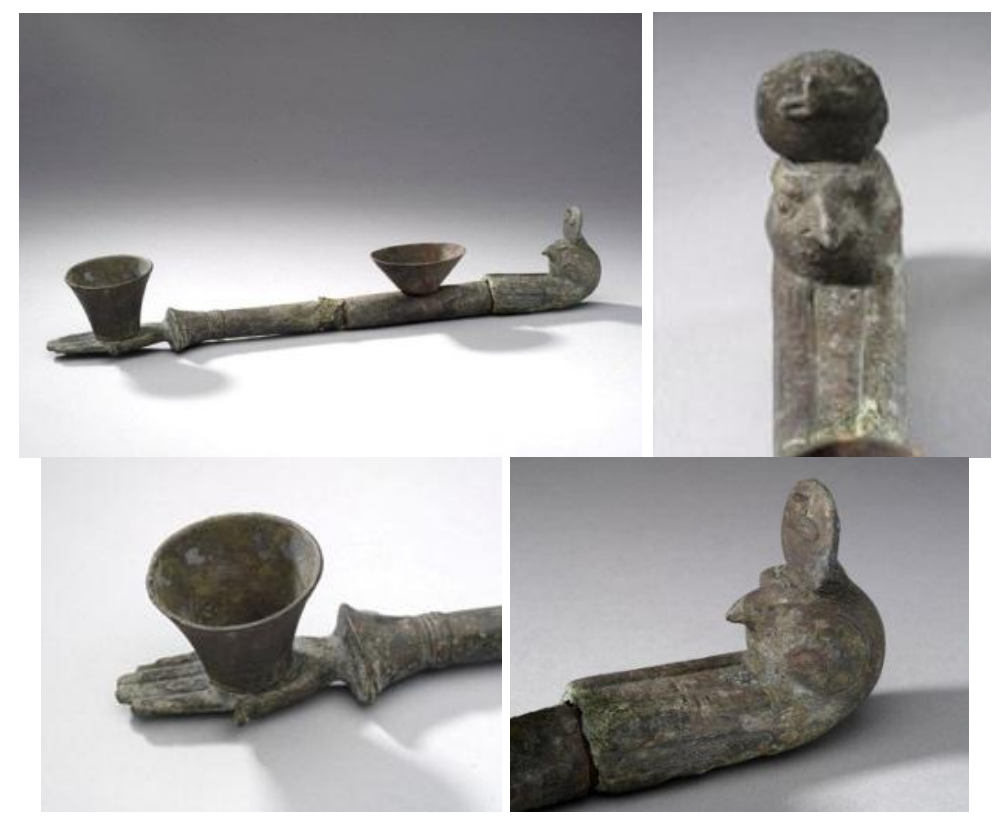

(Cat.9) Egyptian incense burner

Date: 100 BC. - 300 AD.

Dimensions: 1. 43.7, H. 8.1, W. $6.5 \mathrm{~cm}$.

Provenance: Egypt.

Inventory: 909.80.613. Galleries of Africa in the Royal Ontario Museum, Canada.

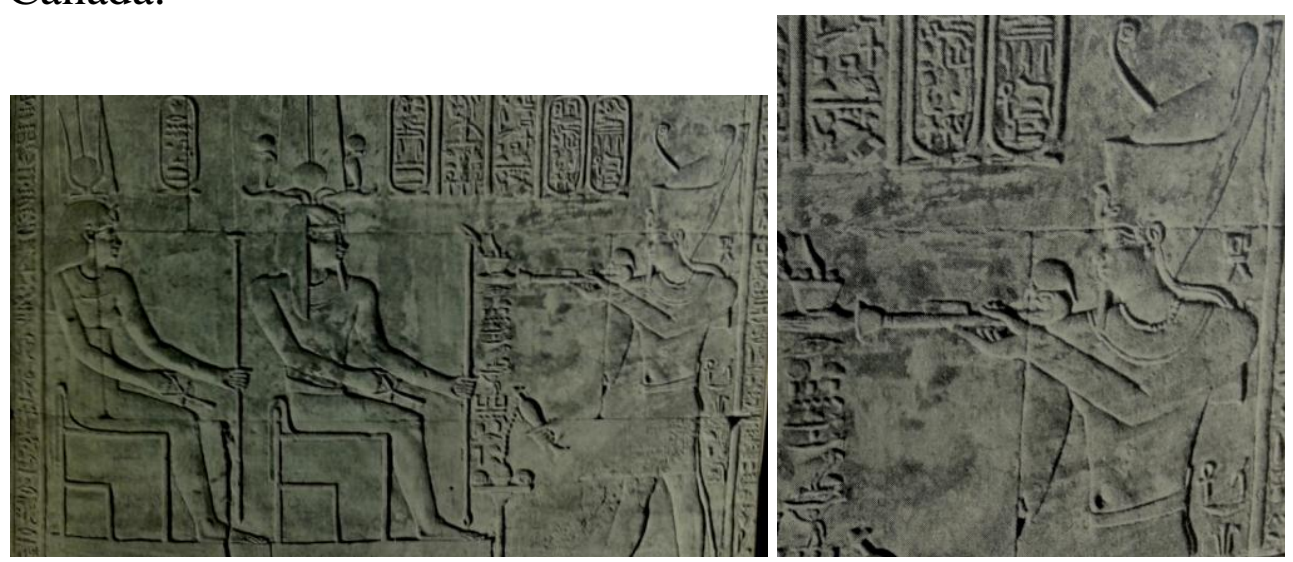

(Cat.10) Ptolemy IV offers Egyptian Incense burner.

Date: Ptolemaic period.

Material: Limestone.

Place: Hall of altar at Edfu. 


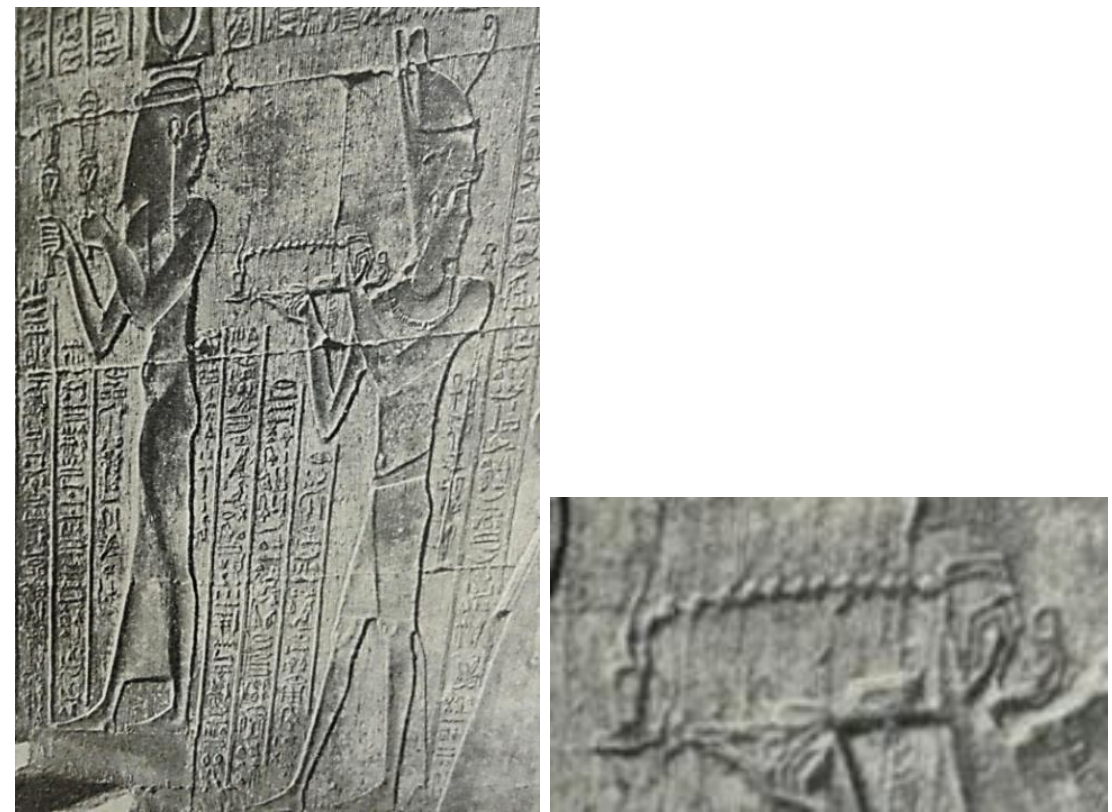

(Cat.11) Ptolemy VIII offers Egyptian Incense burner.

Date: Ptolemaic period.

Material: Limestone.

Place: East staircase in Edfu temple.
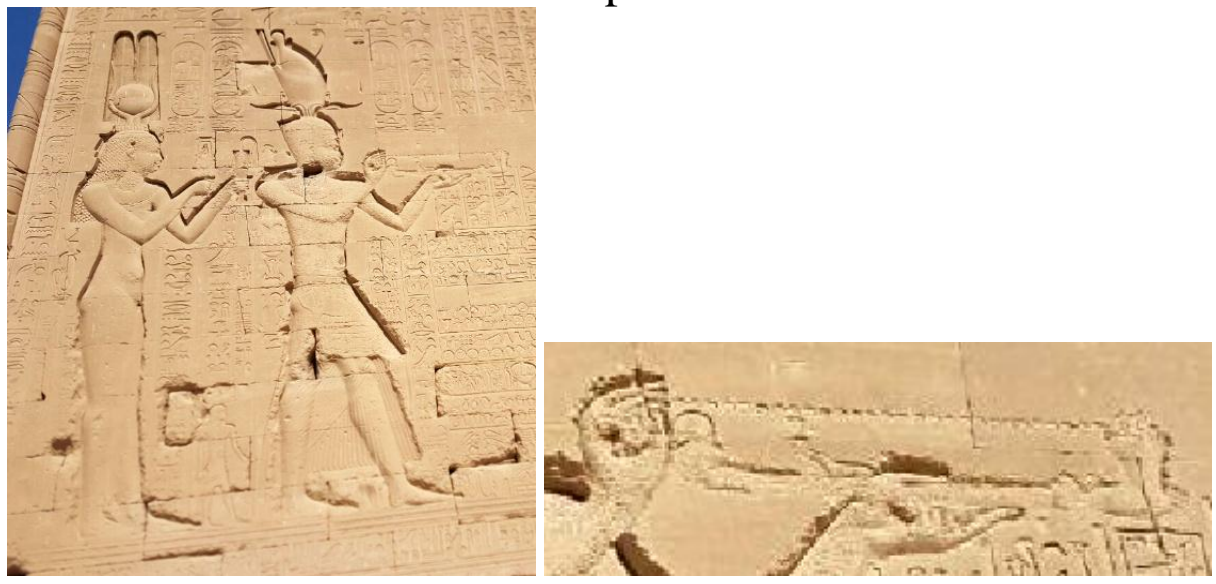

(Cat.12) Caesarion offers Egyptian Incense burner.

Date: Ptolemaic period.

Material: Limestone.

Place: The south wall In Dendera temple.

Photo by: Rewan Said. 

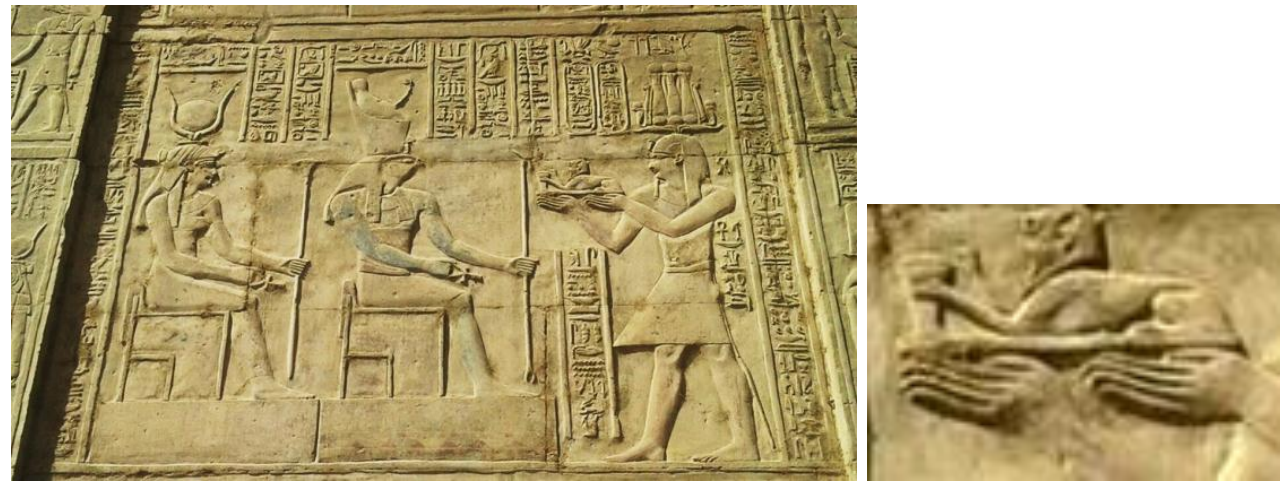

(Cat.13) Ptolemy VI offers Egyptian Incense burner.

Date: Ptolemaic period.

Material: Limestone.

Provenance: Temple of Sobek and Haroeris at Kom Ombo.

Photo by: Ahmed abu Elsoud. 

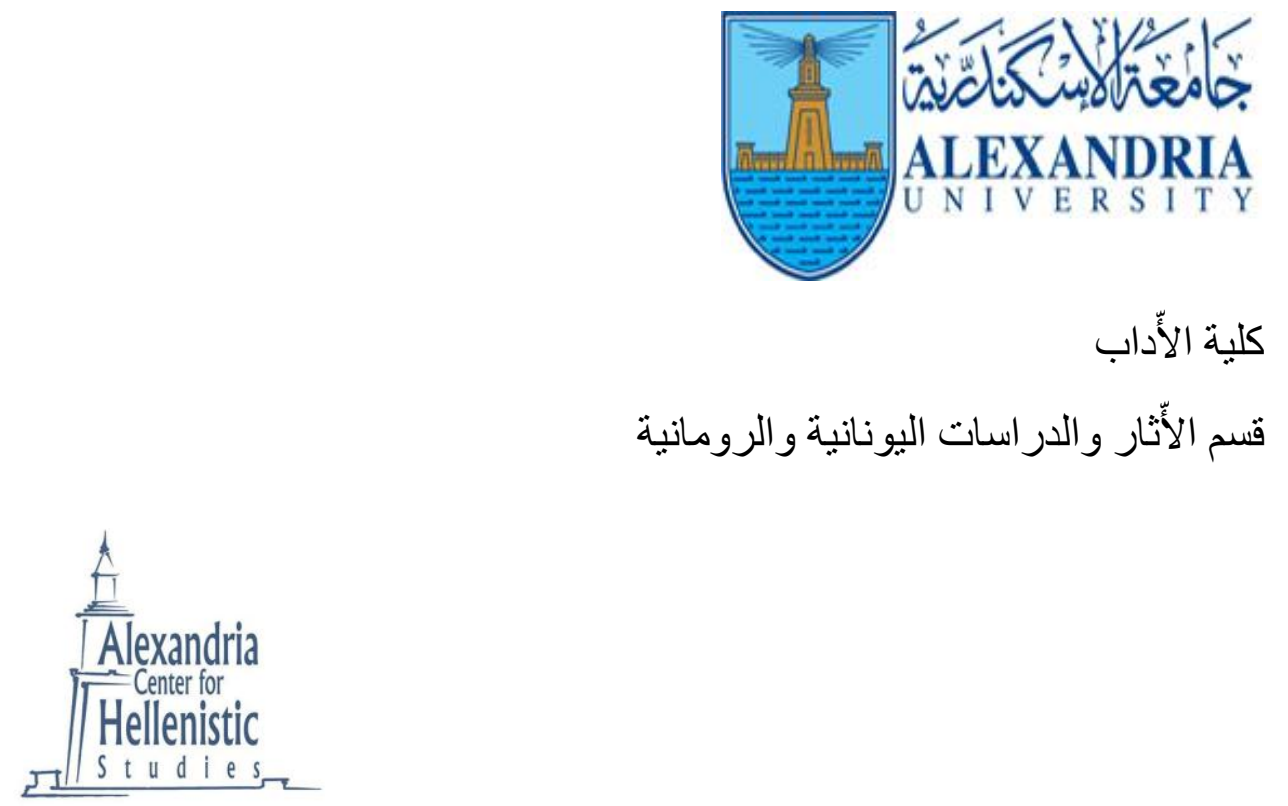

مركز إسكندرية للار اسات الهللينستية

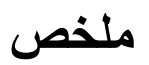 \\ أدلة على الإستيعاب الفنى من خلال دراسة المباخر البطلمية}

مها محمد حسن

$(r \cdot 11)$ 


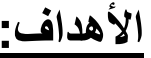

يتجه هذا البحث لعرض المباخر المصرية وتطوراتها الفنية في العصر البطلمى. بالإضافة

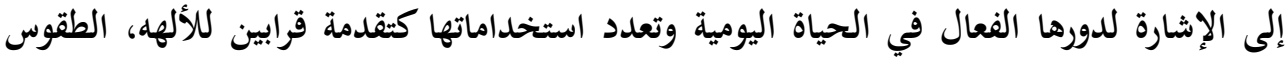
الدينية، العبادات المنزلية والاستخدامات الجنائزية. مقدمة:

تتضمن المقدمة على بعض من مواد البخور مع الإشارة إلى الأنتشار الواسع للمباخر في

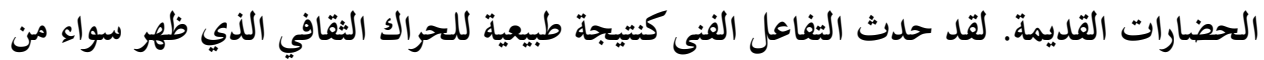
قبل العصر البطلمى أو خلاله.

\section{النقاط الرئيسية:}

هذا البحث يلقى الضوء على طرز و أشكال المباخر البطلمية طبقا لثلاث نقاط رئيسية:

$$
\begin{aligned}
& \text { • المباخر قبل العصر البطلمى. } \\
& \text { المباخر خلال العصر البطلمى. } \\
& \text { تعايش الملوك البطالمة والثقاليد المصرية. }
\end{aligned}
$$

\section{الخاتمة:}

تتميز مصر بطراز خاص بها للمباخر من عصر الأسرات والذى استمر إلى العصرين البطلمى والرومانى. إحتفظت مصر بملامحها وتقاليدها المحلية وكذلك تقبلت الثقافة اليونانية وامتزجت بها. 